\title{
Renocolic fistula following a partial nephrectomy: a case study
}

\author{
Hamza Dergamoun ${ }^{1 *} \mathbb{0}$, Youssef Zaoui ${ }^{1}$, David Amielh², Pascal Volpe ${ }^{2}$ and Amine El Kharroubi ${ }^{3}$
}

\begin{abstract}
Background: Uro-digestive fistulae are uncommon. They frequently manifest themselves with mild symptoms but can, in some cases, be life-threatening leading to septic shock and death. The diagnosis is facilitated by radiological explorations and their management remains mainly surgical.

Case presentation: We report the case of a diabetic 62-year-old patient who developed a renocolic fistula revealed by a digestive symptomatology, following a partial nephrectomy that was surgically treated with positive overall outcome.

Conclusion: The development of a fistula between the colon and the kidney is very rare. Although the outcome was positive at the price of total nephrectomy and partial colectomy, the diagnosis and management of the fistula were challenging. Urologists should keep in mind the possibility of a fistula developing in the aftermath of a partial nephrectomy.
\end{abstract}

Keywords: Renocolic fistula, Uro-digestive fistula, Partial nephrectomy, Renal cell carcinoma, Case report

\section{Background}

A renocolic fistula is a communication between the kidney and the colon that is in most cases, secondary to local chronic inflammation. It can also be a result of a trauma, a malignant process or be iatrogenic. Clinical manifestations range from mild fever, diarrhea or fecaluria to septic shock leading to death. The diagnosis is radiological. It can be made by a CT urogram or a fistulogram if cutaneous extension of the fistula is present. The treatment remains surgical and could include a nephrectomy or/ and partial colectomy. Although it can be more conservative in some cases (iatrogenic fistulae).

\section{Case presentation}

An asymptomatic 62-year-old patient was admitted to the urology department following the incidental discovery of a mass on the lower pole of the right kidney. His

\footnotetext{
*Correspondence: hamza.dergamoun@gmail.com

1 Urology A Department, Ibn Sina Teaching Hospital, University Mohammed V, Rabat, Morocco

Full list of author information is available at the end of the article
}

past medical history included midline hernia repair in 2000 and type 2 diabetes since 2010.

The CT urogram study showed a $3 \mathrm{~cm}$ mass on the lower pole of a pelvic located right kidney. The arterial supply to the right kidney was delivered by one main artery and one upper polar artery originating from the aorta, the venous return drained through one main renal vein into the vena cava.

The patient case was assessed in a multidisciplinary concertation meeting that recommended the patient to undergo an open partial nephrectomy. The surgery went without any incident. The bleeding was estimated at $100 \mathrm{cc}$ and cold ischemia time was $24 \mathrm{~min}$. Post-operative care was simple.

Histopathology study identified the tumor as a grade 2 of Fuhrman classification clear cell renal cell carcinoma measuring $3,2 \mathrm{~cm}$. The lesion was contained within a pseudocapsule without surrounding fat invasion. It was classified as pT1a of the American Joint Committee on Cancer (AJCC) TNM system.

A month after discharge, the patient is admitted to the emergency department complaining of chills and 
diarrhea for 8 days. Upon examination, the patient was slightly dehydrated but hemodynamically stable. The blood workout found a high C-reactive protein at $76 \mathrm{mg} / \mathrm{L}$ and an elevated creatinine at $127 \mathrm{mg} / \mathrm{L}$ for an estimated glomerular filtration rate at $52 \mathrm{~mL} / \mathrm{min}$ per $1.73 \mathrm{~m}^{2}$ using MDRD formula. The abdominal ultrasound found a $40-\mathrm{mm}$ fluid collection near the lower pole of the right kidney. This prompted us to prescribe an abdominal CT-scan that found no sign of mesenteric ischemia but confirmed the presence of a 40-mm pararenal urinoma. Seeing no improvement in the patient symptomatology, he underwent a colonoscopy that was normal.

The patient received fluids, antalgics and symptomatic treatment that improved his symptoms. He was discharged days later with a follow-up abdominal CT-scan.

A month later, the patient was seen at a follow-up visit with the result of the abdominal CT-scan that showed a renocolic fistula (Fig. 1).

A second colonoscopy was performed showing the colic orifice of the renocolic fistula at $25 \mathrm{~cm}$ from anal margin.

The decision of the multidisciplinary concertation meeting was to perform a right total nephrectomy with partial colectomy. Upon exploration, a renocolic fistula surrounded by inflammatory tissue was found. The surgery went well. A draining tube was left for $24 \mathrm{~h}$ (Fig. 2).

Histopathology study identified the fistula surrounded by areas of steatonecrosis and angiogenesis without any malignant characteristics. Resection margins were clear.

\section{Discussion}

Many cases of fistulae developing between the subdiaphragmatic digestive tract and the urinary system have been reported in the literature [1]. These fistulae could be secondary to chronic inflammation caused by nonspecific infection (xanthogranulomatous pyelonephritis) or specific infection like in urogenital tuberculosis, radiation therapy, urolithiasis $[2,3]$ or a foreign body $[4,5]$ (ureteral stents, nephrostomy...). Fistulae can also form,

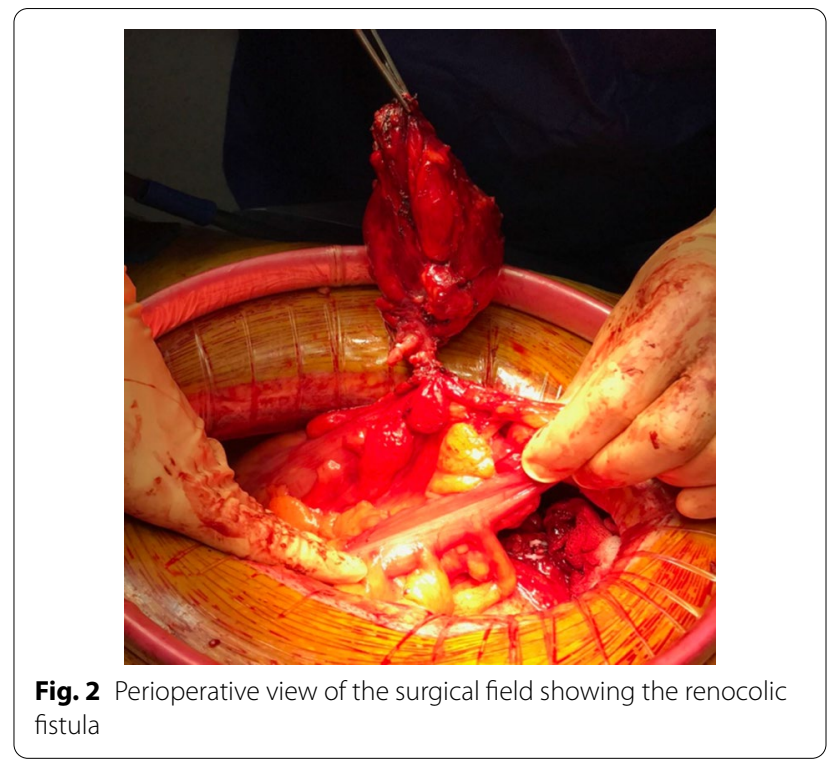

resulting of a traumatism [6,7] that can either be blunt or open (stab wounds or ballistic trauma), or a tumoral process involving either the digestive tract [8] (colonic adenocarcinomas...) or the urinary system [10] (renal cell carcinoma, upper tract transitional cell carcinoma). Some cases of iatrogenic fistulae after the placement of a nephrostomy tube have been reported [5].

The renocolic fistula is the most common location of uro-digestive fistulae. Its development is in most cases a consequence of primary renal pathology. The frequency of this variety of uro-digestive fistulae can be explained by the location and close proximity of the involved organs. It often arises from the development of an acute local inflammatory process leading to chronic perinephritis. The later evolve into an abscess that drains into the adjoining colon, leaving a fistular tract. This phenomenon is more likely to take place in immunocompromised patients.

The clinical presentation is that of a suppurative illness that varies in gravity, from mild symptoms to septic

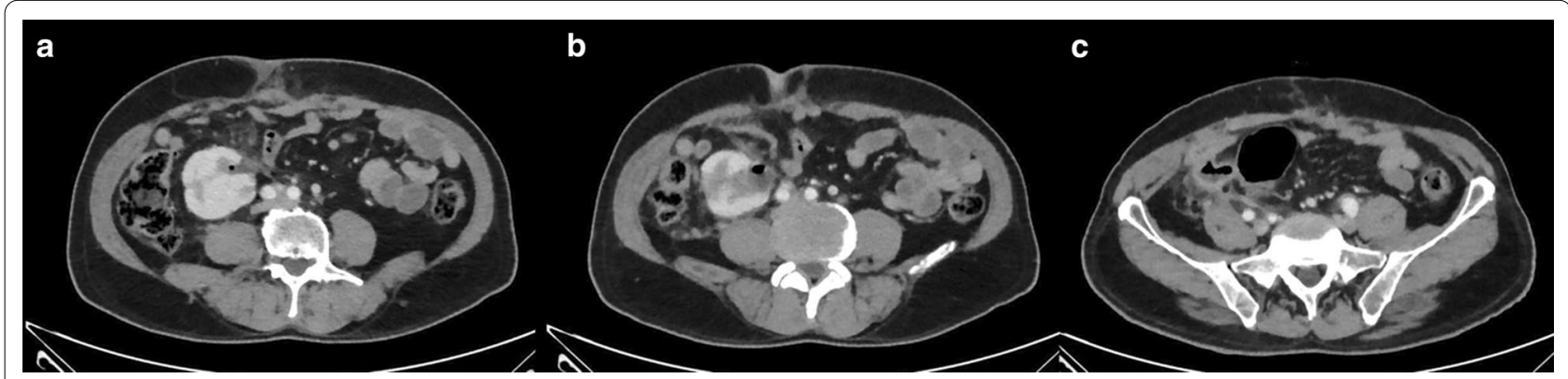

Fig. 1 Abdominal CT-scan showing the renocolic fistula. a, b Air in the renal pelvis, c retroperitoneal fat hyperdensity 
shock. General symptoms include fever, chills, dehydration and weight loss associated with gastrointestinal symptoms like abdominal pain and persistent diarrhea, as seen in the present case. Urinary symptoms like pneumaturia or fecaluria [9] are also reported and can be suggestive of a uro-digestive fistula. Tenderness on palpation of the renal angle can be seen. A cutaneous extension of the fistula has been reported in some cases. [9]

Radiological investigations are the key to the diagnosis in most cases. It can be made either by urinary tract, less often digestive tract, opacifications or by computed tomography demonstrating the fistulous communication. A fistulogram can help to the diagnosis when a cutaneous extension is present. [9]

The management of renocolic fistulae is in most cases surgical. It consists of a nephrectomy since the affected kidney is destroyed by the inflammatory process or contains malignancy, with partial colectomy and primary anastomosis if possible. A more conservative approach can be taken for the management of iatrogenic fistulae caused by instrumentation.

\section{Conclusion}

Renocolic fistula is a rare entity caused either by a local inflammatory process, malignancy or a traumatic event. The diagnosis is nearly always made radiologically and its management is multidisciplinary and is often surgical.

\section{Abbreviations}

AJCC: American Joint Committee on Cancer; TNM: Tumor node metastasis; CT: Computed tomography; MDRD: Modification of diet in renal disease.

\section{Acknowledgements}

Not applicable.

\section{Authors' contributions}

$\mathrm{DH}$ and $\mathrm{ZY}$ researched the literature and wrote the manuscript. $D H, A D, V P$ and KA operated on the patient and had the idea for this case report. ZY checked the manuscript and made corrections. All authors read and approved the final manuscript.

\section{Funding}

None.

\section{Availability of data and materials}

Data sharing is not applicable to this article as no datasets were generated or analyzed during the current study.
Ethics approval and consent to participate

Our institution does not require ethical approval for this case report.

\section{Consent for publication}

Written informed consent was obtained from the patient for publication of this case report and accompanying images.

\section{Competing interests}

The authors declare that they have no competing interests.

\section{Author details}

${ }^{1}$ Urology A Department, Ibn Sina Teaching Hospital, University Mohammed V, Rabat, Morocco. ${ }^{2}$ Clinique Kennedy, Nîmes, France. ${ }^{3}$ Centre Hospitalier Universitaire Caremeau, Place du Professeur Robert Debré, Nîmes, France.

Received: 29 June 2020 Accepted: 14 December 2020

Published online: 22 January 2021

\section{References}

1. Arthur GW, Morris DG (1966) Reno-alimentary fistulae. Br J Surg 53:396-402

2. Mooreville M, Elkouss GC, Schuster A, Pearce AE, Rosen J (1988) Spontaneous renocolic fistula secondary to calculous pyonephrosis. Urology 31:147-150

3. Bahn DK, Brown RK, Reidinger AA, Duhamel PA, Shei KY, Gontina H et al (1988) Renal stone ileus. Am J Roentgenol 150:145-146

4. Lee SW, Kim JH (2009) Renocolic fistula secondary to a perinephric abscess: a late complication of a forgotten double J stent. J Korean Med Sci 24(5):960-962

5. Chalise PR, Sharma UK, Gyawali PR, Shrestha GK, Joshi BR, Ghimire RK (2009) Renocolic fistula following percutaneous nephrostomy: a case report. Nepal Med Coll J 11(2):143-144

6. Lee SD, Kim TN, Ha HK (2011) Delayed presentation of renocolic fistula at 4 months after blunt abdominal trauma. Case Rep Med 2011:103497

7. Abdelaziz H, Adourrouj I, Elabiad Y, Janane A, Ghadouane M, Ameur A et al (2014) Management of renocolic fistula following abdominal trauma from a Gunshot: two cases reports. Can Urol Assoc J 8(3-4):E207-209

8. Manzanilla-Garcia HA, Sanchez-Alvarado JP, Rosas-Nava JE, Soto-Abraham $\checkmark$ (2009) Renocolic fistula secondary to colon adenocarcinoma. Rev Mex Urol 69:299-302

9. Mander BJ, Menzies D, Motson RW (1993) Renocolic fistula. J R Soc Med 86:601-602

10. Blatstein LM, Ginsberg PC (1996) Spontaneous renocolic fistula: a rare occurrence associated with renal cell carcinoma. J Am Osteopath Assoc 96(1):57-59

\section{Publisher's note}

Springer Nature remains neutral with regard to jurisdictional claims in published maps and institutional affiliations.

\section{Submit your manuscript to a SpringerOpen ${ }^{\odot}$ journal and benefit from:}

- Convenient online submission

- Rigorous peer review

- Open access: articles freely available online

- High visibility within the field

- Retaining the copyright to your article

Submit your next manuscript at springeropen.com 